How to cite: Sfícă, L., Nicuriuc, I., Niță, A. (2019) Boundary Layer Temperature Stratification as Result of Atmospheric Circulation Within the Western Side of Brașov Depression. 2019 "Air and Water - Components of the Environment" Conference Proceedings, Cluj-Napoca, Romania, p. 53-64, DOI: 10.24193/AWC2019_06.

\title{
BOUNDARY LAYER TEMPERATURE STRATIFICATION AS RESULT OF ATMOSPHERIC CIRCULATION WITHIN THE WESTERN SIDE OF BRAŞOV DEPRESSION
}

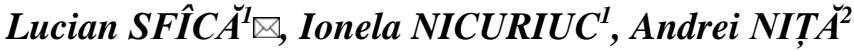

DOI: 10.24193/AWC2019_06

\begin{abstract}
The study explores the connection between the atmospheric circulation and the air temperature stratification in the western part of Brașov depression during 2 years of air temperature monitoring (2013-2014) on fixed points. The monitoring points have covered the low area of the depression (Stupini - $610 \mathrm{~m}$ ), the mountain slopes (Poiana Braşov $-1200 \mathrm{~m}$ ) and the highest point in the region (Vf. Omu $-2500 \mathrm{~m}$ ). On the basis of daily values from these 3 observation points, 6 types of temperature stratification were established. Each of these types of stratification was analyzed according to the daily GWT atmospheric circulation types. The results indicate that the normal stratification prevails along the year, but the temperature inversion and isothermy reach $17 \%$ concerning the mean daily air temperature, $11 \%$ for the maximum daily air temperature and $35 \%$ for the minimum daily air temperature. The temperature inversion situations became prevalent concerning minimum air temperature representing the most common temperature stratification during winter mornings. From dynamic point of view, besides the well-known role of high pressure centers other diverse types of southerly, south-westerly or even westerly atmospheric circulations are related also to the occurrence of most cases of temperature inversion, while the normal stratification is related mostly to intense cyclonic activity in the region of Romania.
\end{abstract}

Keywords: temperature profile, atmospheric circulation, temperature inversion, warm belt, Brașov.

\section{INTRODUCTION}

The western part of Brașov depression represents the largest intermountain basin from Romania. Due to its vast spatial extension and due to its enclosure between mountain ranges, this depression represents implicitly a very important region for the occurrence of the most intense temperature inversions in Romania (Stoenescu, 1951, Teodoreanu, 1980) and, associated to this phenomena, for the occurrence of the record lows of air temperature in Romania. Other authors (Bâzâc, 1983) considered Brașov depression less susceptible for the development of temperature inversion - due to the higher dynamic of cold air advection along the

\footnotetext{
${ }^{1}$ Faculty of Geography and Geology, Alexandru Ioan Cuza University of Iași, sfical@yahoo.com nicuriuc@yahoo.com

${ }^{2}$ Romanian Meteorological Administration, nitandru@gmail.com
} 
Olt valley - in comparison with Giurgeu and Ciuc depression. However, in this region, at Bod, $10 \mathrm{~km}$ north of Braşov, on 25 of January 1942 the absolute minimum air temperature in Romania was recorded $\left(-38.5^{\circ} \mathrm{C}\right)$. It is relevant to mention that this value was recorded during a period of strong temperature inversion in the region, as indicated by the value of $-24.0^{\circ} \mathrm{C}$ recorded at the same date on Vârfu Omu (Stoenescu, 1951, Mihai, 1975).

The climatic features of this region - with focus on temperature features - were tackled directly in some climatic studies in the region. In this regard, the most important contribution resides in the study conceived by Elena Mihai (1975) focused on climatic features of Brașov depression. A lot of attention was given in this study to the temperature characteristics, with a special focus on temperature inversions which has been found to have an important impact on vertical temperature gradient, but also on the mean annual air temperature within the depression. Previously, Mihai and Teodoreanu (1969), using 4 years of daily observations at Brassov, Predeal and Vf. Omu, estimated the absolute annual frequency of temperature inversions at cca. 57 days taking to account the minimum daily temperature. As well, in this study it was evaluated that most frequently the temperature inversions are associated with anticyclonic conditions (57\%) - specific for winters - and secondly with advective conditions (39\%) found to be common during transitional seasons. More recently, Ciulache (2006) studied some topoclimatic and microclimatic features of Braşov city and evaluated the frequency of temperature inversions for minimum temperature at 64\% (233 days) between Braşov weather station (609 m) and Ghimbav (534 m). The same author underlined the role of the urban heat island determined by the Brașov city (situated at higher altitude than Ghimbav weather station) that complicate the understanding of temperature inversions in low area of Brașov depression. This is the reason for which we have not used Braşov weather station data in our study despite their availability. Besides the studies listed above, some contributions were brought recently by other authors focusing on forestry climatology (Marcu and Huber, 2003).

The high frequency of air temperature inversions in the area has an important environmental impact. For instance, we can consider this high frequency of temperature inversion in low area of Brassov depression as the main explanation for the lack of temperature trend observed for Brașov weather station during the last decennia in Romania (Tomozeiu et al., 2002). Also, the higher variability of snow pack in lower mountains (Micu, 2009) could be related to the high frequency of temperature inversion at this level.

In our study, using the data collected from a monitoring network installed in the region, a description of vertical temperature conditions has been made in the western sector of Brașov depression (Țara Bârsei) during 2013-2014. Secondly, the synoptic conditions determining the different types of temperature stratification were analyzed. A special focus was put on the synoptic causes of temperature inversions, due to their high importance for numerous climatic and geographic characteristics of intermountain regions and their surroundings areas (Barry, 2008, Paraschiv, 2009) being considered for the Romanian Carpathians one of the most important factors for the extension of biogeographical areas inside the mountain sectors (Stoenescu, 1951). 


\section{DATA AND METHODS}

The actual technical progress in the field of atmospheric measurements offers a large possibility for monitoring air meteorological parameters at relatively low costs. In this matter, 2 weather shelters geared with CEM-171 data loggers were installed in low area of Brașov depression at Stupini $(610 \mathrm{~m})$ and in the middle mountain sector at Poiana Brașov $(1200 \mathrm{~m})$ in standard monitoring conditions. Beside this, we have used in this study the daily air temperature at Vf. Omu $(2505 \mathrm{~m})$ from Romanian Meteorological Administration (Climate Prediction Center, 2018).

Using the results of the monitoring campaign we have obtained a detailed vertical profile of the air temperature in this area for 2013-2014, from the bottom of the depression to its surrounding mountain peaks, which corresponds generally to lower troposphere. Based on daily mean, maximum and minimum air temperature at the 3 monitoring points 6 types of air temperature stratification were established (Fig. 1): normal stratification (a), absolute inversions (f), partial inversions with 2 subtypes (with cold or warm valleys - d and e) and altitude inversions with 2 subtypes (with cold and warm valleys - b and c ). Additionally, all the days for each the temperature recorded at least two monitoring points was similar were assigned to a separate group corresponding to isothermal conditions.

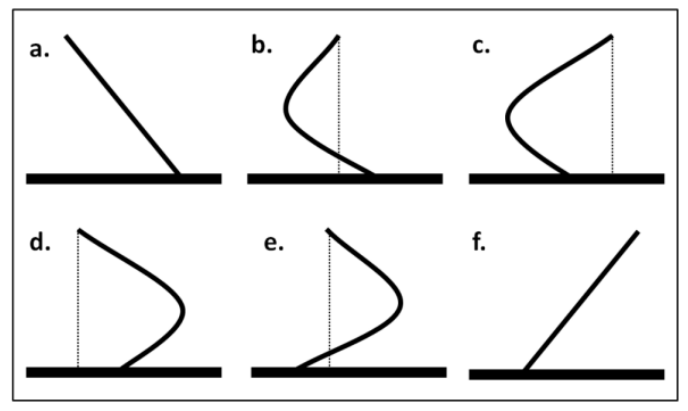

Fig. 1. Types of temperature stratification between Stupini, Poiana Brașov and Vf. Omu (a. normal stratification-NS; b. altitude inversion - warmer at the bottom - AIWB; $c$. altitude inversion - colder at the bottom - AICB; d. relative inversion - warmer at the bottom - RIWB; e. relative inversion - colder at the bottom - RICB; f. absolute inversion)

In this study, Gross Wetter Typen (GWT) based on threshold criteria was used as classification scheme of atmospheric circulations (Beck, 2000). This classification was run out using the daily mean-sea-level-pressure at 12 UTC (MSLP) data from ECMWF Era-Interim reanalysis (Dee et al., 2011) and cost733class software (Philipp et al., 2010). The basic idea of the GWT classification is to characterize the circulation patterns in terms of varying degrees of zonality, meridionality and vorticity of the large scale mean sea level pressure field (Beck et al., 2007). In this way a so-called objective classification was conceived with 18 atmospheric circulation types, as described in Fig. 2. They include anticyclonic circulation types (as 13-16 or 18), cyclonic circulation types (as 1-2 or 17) and intensive advective 
circulation types. The classification was done for 1979-2017 period, from which in our study only 2013 and 2014 were selected.

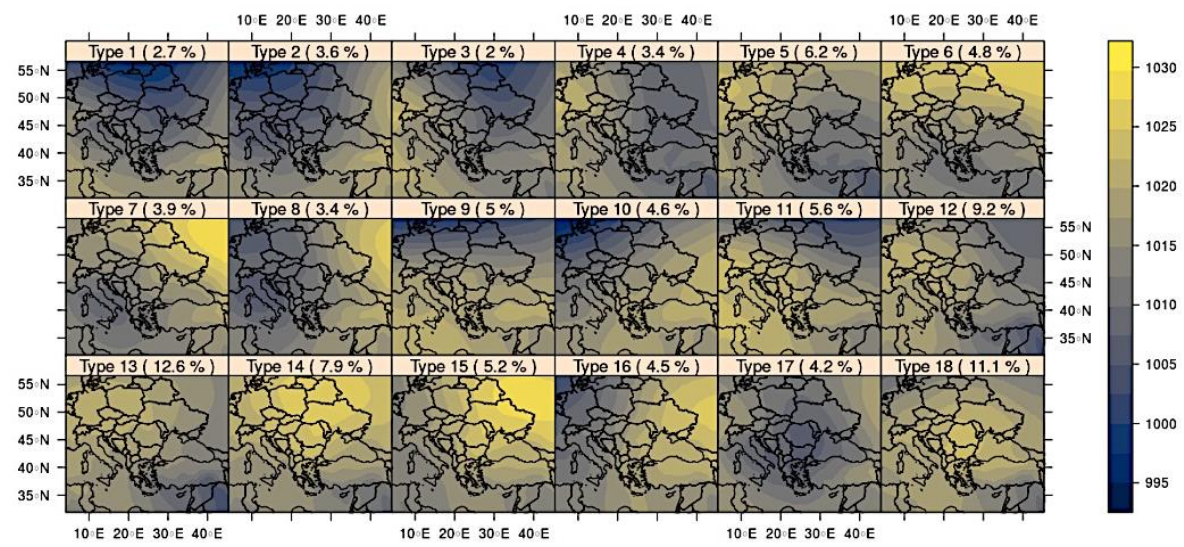

Fig. 2. Types of atmospheric circulation according to Grosswettertypes classification for the region of Romania

In brief, the results of this classification indicate that only 6 circulation types explain $52.6 \%$ of the daily atmospheric circulation. Among these types, the anticyclonic conditions are prevailing (\#11,\#12, \#13,\#18). These circulation types are characterized by the presence of high pressure centers above the region of Romania or above Central Europe. This feature of atmospheric circulation in the region of Romania is of high importance due to the well-known role of anticyclonic conditions in the development of temperature inversions. Actually, GWT results sustain objectively the ideas of other researchers (Stoica, 1962, Stăncescu et al., 1986, Sfîcă, 2007) pointing out that in Romania the frequency of anticyclonic conditions is around $35 \%$ and that they represent the dominant atmospheric conditions in these regions of European continent.

In this way, each day is assigned to a specific GWT atmospheric circulation, but also to a corresponding temperature stratification on Braşov depression. The analysis in our study consists in the interpretation of these results.

Air temperature outlook for 2013-2014. During the observation period the overall weather conditions from the point of view of air temperature were above the climatic normal with $1.5-2^{\circ} \mathrm{C}$, according to NCEP/NCAR database (Kalnay, 1996).

The general features of air temperature characteristics are presented in Tab. 1 . In the low area of the Brașov basin, at Stupini, the annual mean air temperature was $9.7^{\circ} \mathrm{C}, 7.8^{\circ} \mathrm{C}$ at Poiana Braşov in the middle mountain sector and $-1.0^{\circ} \mathrm{C}$ at Vârfu Omu at $2505 \mathrm{~m}$, values which are $1.5^{\circ} \mathrm{C}$ higher as the mean of Vârfu Omu for 1960-2010 (Sandu et al., 2008). The maximum air temperature has reached $34.3^{\circ} \mathrm{C}$ at Stupini, $31.1^{\circ} \mathrm{C}$ at Poiana Brașov and $16.5^{\circ} \mathrm{C}$ at Vf. Omu, all the values being recorded during a singular heat wave which affected entire Romania in August 2013. As well, the minimum air temperature for the observation period has reached $-22.7^{\circ} \mathrm{C}$ at Stupini, $-26.5^{\circ} \mathrm{C}$ at Vf. Omu, but it remained higher in the 
middle mountain sector at Poiana Braşov $\left(-19.8^{\circ} \mathrm{C}\right)$, a fact that underlines the importance of air temperature inversion in the region who is often associated with a warm slope area felt from $650 \mathrm{~m}$ (Marcu and Huber, 2002) and reaching its peak intensity around $900-1300 \mathrm{~m}$. The same vertical distribution is observed for all the parameters concerning the minimum air temperature, as a result of the same temperature stratification (Table 1).

In fact, the importance of temperature inversion is indicated directly by the temperature gradient not exceeding $0,3^{\circ} \mathrm{C} / 100 \mathrm{~m}$ for Stupini - Poiana Braşov sector at annual level, representing a result of the high frequency of stable stratifications in the low area of the depression. Above this level, the air temperature gradient increases, reaching $0.7^{\circ} \mathrm{C} / 100 \mathrm{~m}$ between Poiana Braşov and Vf. Omu, a fact that indicates the higher degree of atmospheric instability at higher altitudinal levels.

Table 1. Annual daily air temperature characteristics in western part of Brașov depression area (2013-2014)

\begin{tabular}{|c|c|c|c|c|c|c|c|c|c|}
\hline & \multicolumn{3}{|c|}{ Stupini } & \multicolumn{3}{c|}{ Poiana } & \multicolumn{3}{c|}{ Vf. Omu } \\
\cline { 2 - 11 } & Mean & Max & Min & Mean & Max & Mini & Mean & Max & Min \\
\hline Mean & 9.7 & 24.9 & -17.0 & 7.8 & 24.2 & -15.7 & -1.0 & 12.2 & -24.5 \\
\hline Max & 15.9 & 34.3 & -10.9 & 12.7 & 31.1 & -10.7 & 1.5 & 16.5 & -22.5 \\
\hline Min & 4.4 & 19.5 & -22.7 & 3.5 & 17.7 & -19.8 & -3.5 & 10.1 & -26.5 \\
\hline
\end{tabular}

Overall, the values recorded during the observation period (2013-2014) could be considered as very relevant for the actual state of the climate, so that our results regarding the temperature stratification and their associated synoptic conditions could be considered as having a remarkable degree of representativeness for the current climate conditions.

\section{RESULTS AND DISCUSSIONS}

\subsection{Temperature stratification in Brașov depression}

a. Temperature stratification for mean daily air temperature. At annual level, the different types of temperature inversions gather $15 \%$ of all days, being recorded exclusively during the cold season (October to March) when their frequency increases to almost 30\% (Table 2). More than half of the days with temperature inversions are recorded in January and December (cca. 7 days per month), followed by February and November (4 days per month). It is important to mention that the temperature inversion identified for daily mean temperature are the results of very intense and long temperature inversion at hourly level. This type of temperature inversions is causing lower values of mean air temperature during all winter months for Bod $(508 \mathrm{~m})$ comparatively to Brașov $(606 \mathrm{~m})$ weather station, as indicated by Mihai (1975).

The partial inversions, with warmer layers at the bottom of the depression (RIWB), are the most common (12.5\% at annual level and $24.8 \%$ at cold season) 
among all the inversions types. Also, altitude inversion - indicating warmer layers of air in top of the mountain than at middle mountain levels - occurs especially in December and January.

Table 2. Relative frequency (\%) of mean daily air temperature stratification in the western part of Brașov depression

\begin{tabular}{|c|c|c|c|c|c|c|c|}
\hline Mean & NS & AIWB & AICB & RIWB & RICB & AI & I \\
\hline I & 46.8 & 1.6 & 6.5 & 40.3 & 1.6 & 0.0 & 3.2 \\
\hline II & 67.9 & 0.0 & 0.0 & 32.1 & 0.0 & 0.0 & 0.0 \\
\hline III & 85.5 & 0.0 & 0.0 & 1.6 & 0.0 & 0.0 & 12.9 \\
\hline IV & 100.0 & 0.0 & 0.0 & 0.0 & 0.0 & 0.0 & 0.0 \\
\hline V & 100.0 & 0.0 & 0.0 & 0.0 & 0.0 & 0.0 & 0.0 \\
\hline VI & 100.0 & 0.0 & 0.0 & 0.0 & 0.0 & 0.0 & 0.0 \\
\hline VII & 100.0 & 0.0 & 0.0 & 0.0 & 0.0 & 0.0 & 0.0 \\
\hline VIII & 100.0 & 0.0 & 0.0 & 0.0 & 0.0 & 0.0 & 0.0 \\
\hline IX & 100.0 & 0.0 & 0.0 & 0.0 & 0.0 & 0.0 & 0.0 \\
\hline X & 77.4 & 0.0 & 0.0 & 19.4 & 0.0 & 0.0 & 3.2 \\
\hline XI & 71.7 & 0.0 & 0.0 & 25.0 & 1.7 & 0.0 & 1.7 \\
\hline XII & 38.7 & 4.8 & 4.8 & 30.6 & 6.5 & 1.6 & 12.9 \\
\hline Annual & $\mathbf{8 3 . 5}$ & $\mathbf{0 . 6}$ & $\mathbf{1 . 0}$ & $\mathbf{1 2 . 5}$ & $\mathbf{0 . 8}$ & $\mathbf{0 . 1}$ & $\mathbf{1 . 5}$ \\
\hline Cold season & $\mathbf{6 4 . 7}$ & $\mathbf{1 . 1}$ & $\mathbf{1 . 9}$ & $\mathbf{2 4 . 8}$ & $\mathbf{1 . 6}$ & $\mathbf{0 . 3}$ & $\mathbf{5 . 7}$ \\
\hline Warm season & $\mathbf{1 0 0 . 0}$ & $\mathbf{0 . 0}$ & $\mathbf{0 . 0}$ & $\mathbf{0 . 0}$ & $\mathbf{0 . 0}$ & $\mathbf{0 . 0}$ & $\mathbf{0 . 0}$ \\
\hline
\end{tabular}

Temperature stratification for maximum daily air temperature. The frequency of temperature inversions is lower at annual (8.9\%) and at cold season level $(17.3 \%)$ for maximum daily temperature than for the mean daily temperature, as a result of the instability induced by the warming of the ground during the day (Table 3). The mean features are very similar to those corresponding to the previous parameter. The temperature inversions are concentrated between December and March with their peak reached in January with $50 \%$ frequency of isothermy or inversions.

Temperature stratification for minimum daily air temperature. The minimum daily air temperature represents the most important parameter to express the characteristics of temperature inversions (Table 4). Our results show that in Brașov depression the normal stratification of the air temperature has a frequency of $65 \%$ at annual level. Having in mind that atmospheric stability includes also normal stratification - with a very low temperature gradient $\left(0.6^{\circ} \mathrm{C} / 100 \mathrm{~m}\right)$ - it became clear that the stable stratification represents the common state of the vertical temperature distribution in the study area.

A particular feature is given by the high frequency of relative inversions with the lowest temperature on the bottom of Brassov depression (RICB). Stoenescu (1951) give the first outlook of temperature inversions on the Vf. Omu - Bod vertical profile, using data for 1941-1945 during which 31,4 days with inversions at 8AM were recorded (maximum in January - 7.0 days). In our study the similar parameter is estimated at only 19 days (5.3\% at annual level and $10.2 \%$ for cold 
season). This is probably influenced by the short period of observation but also could represent a consequence of the current climate change.

Table 3. Relative frequency (\%) of maximum daily air temperature stratification in the western part of Brașov depression

\begin{tabular}{|c|c|c|c|c|c|c|c|}
\hline Maximum & NS & AIWB & AICB & RIWB & RICB & AI & I \\
\hline I & 50.0 & 0.0 & 0.0 & 41.9 & 3.2 & 0.0 & 4.9 \\
\hline II & 78.6 & 0.0 & 0.0 & 21.4 & 0.0 & 0.0 & 0.0 \\
\hline III & 79.0 & 0.0 & 0.0 & 19.4 & 0.0 & 0.0 & 1.6 \\
\hline IV & 96.7 & 0.0 & 0.0 & 1.7 & 0.0 & 0.0 & 1.6 \\
\hline V & 100.0 & 0.0 & 0.0 & 0.0 & 0.0 & 0.0 & 0.0 \\
\hline VI & 100.0 & 0.0 & 0.0 & 0.0 & 0.0 & 0.0 & 0.0 \\
\hline VII & 100.0 & 0.0 & 0.0 & 0.0 & 0.0 & 0.0 & 0.0 \\
\hline VIII & 100.0 & 0.0 & 0.0 & 0.0 & 0.0 & 0.0 & 0.0 \\
\hline IX & 100.0 & 0.0 & 0.0 & 0.0 & 0.0 & 0.0 & 0.0 \\
\hline X & 95.2 & 0.0 & 0.0 & 0.0 & 0.0 & 0.0 & 4.8 \\
\hline XI & 93.3 & 1.7 & 0.0 & 3.3 & 0.0 & 0.0 & 1.7 \\
\hline XII & 61.3 & 4.8 & 0.0 & 17.7 & 8.1 & 1.6 & 6.5 \\
\hline Annual & $\mathbf{8 9 . 0}$ & $\mathbf{0 . 6}$ & $\mathbf{0 . 0}$ & $\mathbf{8 . 9}$ & $\mathbf{1 . 0}$ & $\mathbf{0 . 1}$ & $\mathbf{0 . 4}$ \\
\hline Cold season & $\mathbf{7 6 . 2}$ & $\mathbf{1 . 1}$ & $\mathbf{0 . 0}$ & $\mathbf{1 7 . 3}$ & $\mathbf{1 . 9}$ & $\mathbf{0 . 3}$ & $\mathbf{3 . 2}$ \\
\hline Warm season & $\mathbf{9 9 . 4}$ & $\mathbf{0 . 0}$ & $\mathbf{0 . 0}$ & $\mathbf{0 . 3}$ & $\mathbf{0 . 0}$ & $\mathbf{0 . 0}$ & $\mathbf{0 . 3}$ \\
\hline
\end{tabular}

As observed by Stoenescu (1951), the cold season represents the main interval of temperature inversion occurrence. Our analysis show for minimum air temperature a frequency of $52.1 \%$ of temperature inversions, with a peak in January reaching $69.4 \%$ (17 days per month). The absolute inversions at daily level are sparse (just one case - in December - in 2 years of observation) as observed previously in the Carpathians (Bâzâc, 1983). As well, it is worth mentioning that the daily temperature inversions are not observed during warm season.

Table 4. Relative frequency (\%) of air minimum daily air temperature stratification in the western part of Brașov depression

\begin{tabular}{|c|c|c|c|c|c|c|c|}
\hline Minimum & NS & AIWB & AICB & RIWB & RICB & AI & I \\
\hline I & 30.6 & 8.1 & 1.6 & 32.3 & 19.4 & 3.2 & 4.8 \\
\hline II & 66.1 & 0.0 & 0.0 & 21.4 & 10.7 & 0.0 & 1.8 \\
\hline III & 56.5 & 6.5 & 0.0 & 24.2 & 0.0 & 0.0 & 12.8 \\
\hline IV & 58.3 & 0.0 & 0.0 & 28.3 & 0.0 & 0.0 & 13.4 \\
\hline V & 88.7 & 0.0 & 0.0 & 8.1 & 0.0 & 0.0 & 3.2 \\
\hline VI & 91.7 & 0.0 & 0.0 & 8.3 & 0.0 & 0.0 & 0.0 \\
\hline VII & 83.9 & 0.0 & 0.0 & 16.1 & 0.0 & 0.0 & 0.0 \\
\hline VIII & 85.5 & 0.0 & 0.0 & 12.9 & 0.0 & 0.0 & 1.6 \\
\hline IX & 73.3 & 0.0 & 0.0 & 23.3 & 1.7 & 0.0 & 1.7 \\
\hline X & 40.3 & 0.0 & 0.0 & 37.1 & 14.5 & 1.6 & 6.5 \\
\hline XI & 61.7 & 3.3 & 0.0 & 23.3 & 8.3 & 0.0 & 3.4 \\
\hline XII & 32.3 & 1.6 & 1.6 & 33.9 & 8.1 & 4.8 & 17.7 \\
\hline Annual & $\mathbf{6 4 . 9}$ & $\mathbf{1 . 7}$ & $\mathbf{0 . 3}$ & $\mathbf{2 2 . 8}$ & $\mathbf{5 . 3}$ & $\mathbf{0 . 8}$ & $\mathbf{4 . 2}$ \\
\hline Cold season & $\mathbf{4 7 . 9}$ & $\mathbf{3 . 2}$ & $\mathbf{0 . 5}$ & $\mathbf{2 8 . 7}$ & $\mathbf{1 0 . 2}$ & $\mathbf{1 . 6}$ & $\mathbf{7 . 9}$ \\
\hline Warm season & $\mathbf{8 0 . 2}$ & $\mathbf{0 . 0}$ & $\mathbf{0 . 0}$ & $\mathbf{1 6 . 2}$ & $\mathbf{0 . 3}$ & $\mathbf{0 . 0}$ & $\mathbf{3 . 3}$ \\
\hline
\end{tabular}


For the minimum daily temperature, the inversions are occurring also in warm season $(16.2 \%)$ considered from April to September with the lowest occurrence in May and June (cca. 8\% - 3 day per month), which are known for their higher degree of atmospheric instability. The RIWB type of temperature inversion remained the most frequent ( $22.8 \%$ for annual level and $28.7 \%$ for cold season). Interestingly, this type reach its maximum in October, a month of maximum anticyclone activity in region of Romania.

Bâzâc (1983) showed that the absolute inversions, or total inversions as defined by the author, are very rare ( 2 cases in 5 years in Tarcu Mountains) and are triggered especially by the warm air advection in the middle troposphere, reaching the mountain peaks, while the slope of the mountains and the depressions remain in the cold air lake. In our study this absolute inversion was recorded only in 3 days for the minimum daily air temperature.

\subsection{Atmospheric circulation associated with different types of air temperature stratification}

For the normal air temperature stratification, the most frequent circulation types - with more than $6 \%$ - are characterized by an easterly or south-easterly circulation (\#5, \#6, \#7), north and north-westerly circulation (\#12, \#13) or situations with cyclones or anticyclones over the region of Romania.

Easterly or south-easterly circulations (\#5,\#6,\#7) are typical synoptic patterns representative for the action of Mediterranean cyclones. These conditions induce a very high atmospheric instability that corresponds with the high temperature gradient in the study region.

North and north-westerly circulations (\#12, \#13) are bringing in Romania polar maritime air masses that are generally unstable especially due to the warming of the lower layers of the atmosphere over the continent. Another possible explanation resides in the fact that these advections are following more warmer periods after which the bottom layers of the troposphere remain warmer while the colder air from the advection are propagating in altitude.

The temperature normal stratification is common for the cyclonic circulation type (\#17) associated to its corresponding instability, but also for the anticyclonic circulation type (\#18) which is somehow surprisingly since anticyclonic conditions are known to be associate to the opposite situation of temperature inversion and atmospheric stability. Our results show that in anticyclonic conditions during summer the high insolation determines an intense warming of the surface that causes the normal stratification.

The contribution of these circulation types is similar for for mean, maximum and minimum air temperature (Fig. 3) with just a slight decrease of the anticyclonic conditions determining normal stratification on minimum daily temperature as a result of radiative inversion that occur on the bottom of the depression in summer under the action of anticyclones.

Concerning the altitude inversions, these situations are rare and generally are related to anticyclonic situations (\#18) or with intense southerly advection in 
anticyclonic conditions (\#15 or \#7). Generally, they represent transitional situations that are not lasting more than 1 day.

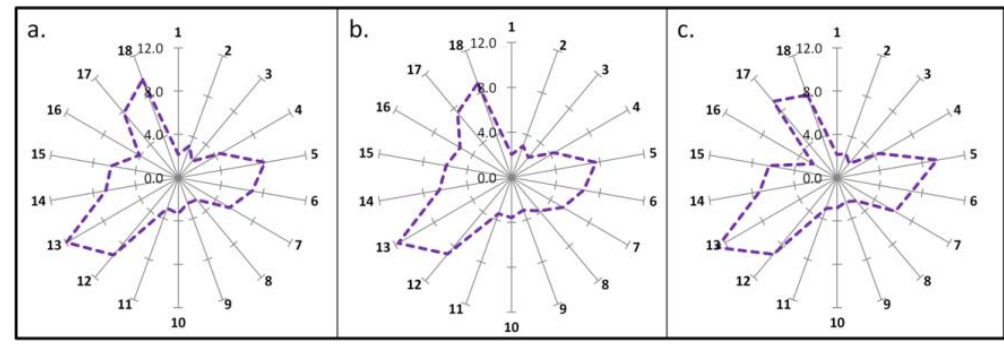

Fig. 3. The contribution of GWT circulation types for the occurrence of normal stratification for mean (a), maximum (b) and minimum (c) air temperature

The partial inversions, which are the most representative type of inversions in the region, are caused mainly by anticyclonic (\#16) or cyclonic (\#2 and \#8) southerly atmospheric circulations especially concerning mean and maximum daily air temperature. Beside these, south-westerly (\#10) or westerly (\#9) anticyclonic types have an equal contribution to the occurrence of these types of inversions (Fig. 4). In these conditions the warm air reaches firstly the top of the mountains from west and south-west, while the lower levels from Brașov depression are immersed in the well sheltered cold air lake. If the warm advection in upper level is very intense it brings the air temperature at Vf. Omu above the values from the bottom of the depression, the partial inversion being replaced by the absolute inversion.

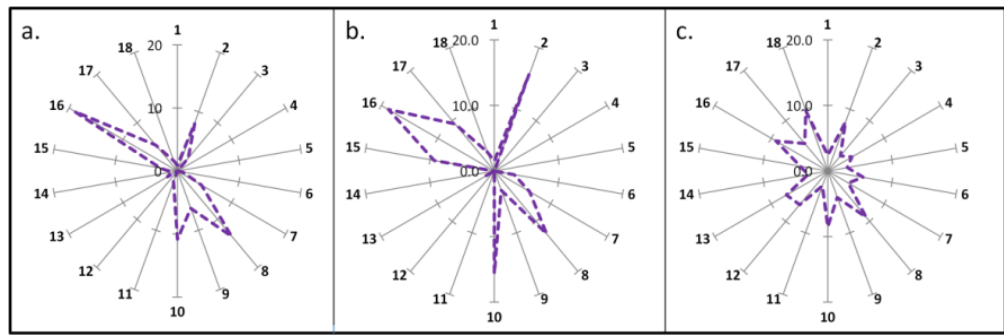

Fig. 4. The contribution of GWT circulation types for the occurrence of relative inversion (warmer at the bottom) for mean (a), maximum (b) and minimum (c) air temperature

Regarding the minimum daily air temperature, the partial inversions are caused in more different atmospheric circulation patterns, in these case the role of the orography being more important than the synoptic pattern.

As rare as the altitude inversions is the absolute inversion when the temperature increase from the bottom of the depression continuously with altitude, the mountain top recording the highest temperature. In 2013-2014 this situation was recorded only for 4 days being included in westerly (\#9 on 20.12.2013) and southwesterly (\#10 on 1.01.2013 and 22.12.2013, \#16 on 19.12.2013) circulation types on GWT classification. 
Using NOAA reanalysis archive we have observed that the record low temperature in Romania from 25 of January 1942 (Fig. 5) occurred in conditions of intense southerly advection in south-east Europe which induced an absolute inversion profile in Brașov depression as mentioned in previous study (Mihai, 1975). This circulation corresponds with \#8 circulation type in the GWT atmospheric circulation applied in this study, representing an intense southerly circulation for which the advection evolves in the same conditions as southwesterly and westerly warm advections specific for absolute inversions.

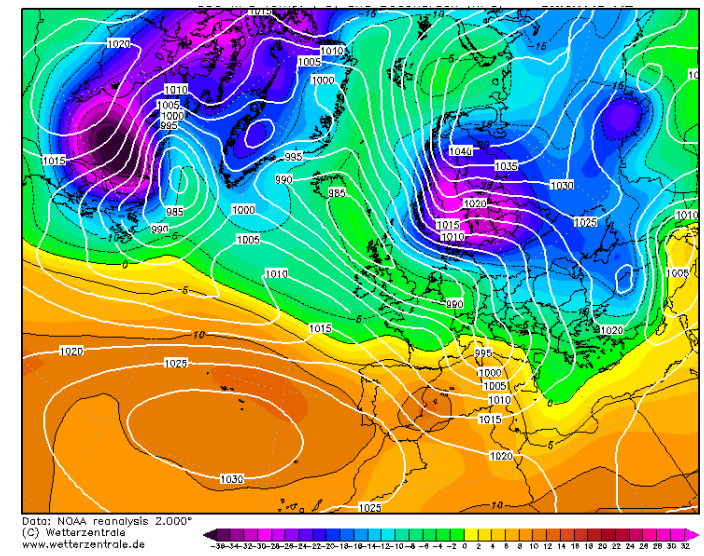

Fig. 5. Sea level pressure (white lines) ant 850 hPa temperature distribution in 25 of January 1942

Another explanation for absolute inversion is given by the advection of the cold air in the lower troposphere (Bâzâc, 1983) while the warmer temperature remain in higher altitude. Most probably due to the short period of our study no such situation was identified.

Taking to account only the air temperature difference between Stupini and Poiana Brașov we can see that the most intense air temperature inversions $\left(>3^{\circ} \mathrm{C}\right)$ are caused by anticyclonic (\#10,\#16) or cyclonic (\#2) south-westerly circulation types (Fig. 6).

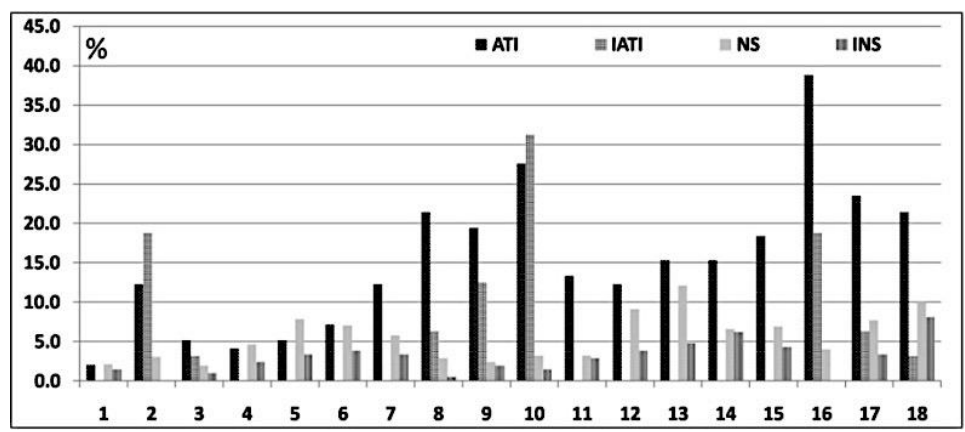

Fig. 6. The role of GWT circulation types for the intensity of different types of air temperature stratification (ATI - air temperature inversions; IATI - intense air temperature inversions, NS - normal stratification, INS - intense normal stratification) 
It is to mention that this type of advection is related in winter with warm spells occurring in the region of Romania (Sfîcă et al., 2017). Very high positive differences between Stupini and Poiana Brașov (INS) are determined by high insolation during anticyclonic conditions (\#14 and \#18) in summer period.

\section{CONCLUSIONS}

Despite the short period of observation, our results are coherent with the previous knowledge on the topic. Additionally, we have shown that the temperature inversions are not occurring only during anticyclonic conditions, but also during southerly or south-westerly advections manifested on the westerly flank of high pressure centers localized in East or South-East Europe. These synoptic patterns can cause an intense warm advection in altitude building-up the temperature inversions above the Braşov depression. In this idea, the most intense temperature inversions represent a result of both warm advection in the altitude combined with radiative cooling on the bottom of the depression inside the cold air lake.

Another finding resides in the observation showing that the warm belt on the slopes of the mountain - specific for partial inversions - is situated at higher level $(1200 \mathrm{~m})$ as considered in the previous studies $(1000 \mathrm{~m})$. This has an important environmental impact on the vegetation and especially on the forestry ecosystems.

Not at last, we have given a clear image of the temperature inversion frequency at monthly and annual level. The temperature inversions and the isothermy occur in 60.2 days at annual level regarding mean daily temperature, in 40.2 days annually for maximum daily temperature and 128.1 days regarding minimum daily temperature. This aspect is very important because these frequencies express directly the risk for the occurrence of atmospheric pollution in the region.

\section{REFERENCES}

1. Barry, R. (2008), Mountain weather and climate, Cambridge University Press, ISBN-13 978-0-521-86295-0, $506 \mathrm{p}$

2. Beck, C. (2000), Zirkulations dynamische Variabilität im Bereich NordatlantikEuropa seit 1780

3. Bâzâc, Gh. (1983), Influența reliefului asupra principalelor caracteristici ale climei României, Ed. Academiei, 179 p

4. Ciulache, S. (2006), Topoclimatic and microclimatic differences in the Braşov townarea, Lucr. sem. geogr. "D. Cantemir", 26 (43-51)

5. Climate Prediction Center/National Centers for Environmental Prediction/National Weather Service/NOAA/U.S. Department of Commerce (1987), CPC global summary of the day/month observations, 1979-continuing. Research Data Archive at National Center for Atmospheric Research, Computational and Information Systems Laboratory, Accessed 15 June 2018.

6. Kalnay, E., Kanamitsu, M., Kistler, R., Collins, W., Deaven, D., Gandin, L., Iredell, M., Saha, S., White, G., Woollen, G., Woollen, J., Chelliah, M., Ebisuzaki, W., 
Higgings, W., Janowiak, J., Mo, K.C., Ropelewski, C., Wang, J., Leetmaa, A., Reynolds, R., Jenne, R., Joseph, D. (1996), The NCEP/NCAR 40 years re-analysis project, Bull. Am. Meteorol. Soc. 17(3):437-471.

7. Mihai, E. (1975), Depresiunea Braşov, studiu climatic, Ed. Academiei, 209 p

8. Mihai, E., Teodoreanu, E. (1969), Frecvența inversiunilor de temperatură în Depresiunea Brașovului, Stud. cerc. geol. geofiz. și geogr., Seria geografie, 16/2: 205-213

9. Teodoreanu, E. (1980), Culoarul Rucăr-Bran - studiu climatic și topoclimatic, Ed. Academiei, $165 \mathrm{p}$

10. Micu, D. (2009), Snow pack in the Romanian Carpathians under changing climatic conditions, Meteorol Atmos Phys (2009) 105:1-16, doi 10.1007/s00703-009-0035-6

11. Paraschiv, V. (2009), The temperature inversions and the environmental risks resulted in the Giurgeu depression, Lucr. sem. geogr. "D. Cantemir", 28 (39-49)

12. Philipp, A., Beck, C., Huth, R., \&Jacobeit, J. (2016), Development and comparison of circulation type classifications using the COST 733 dataset and software. International Journal of Climatology, 36(7), 2673-2691

13. Sandu, I., Pescaru, V.I., Poiană, I., Geicu, A., Cândea, I., Țâștea, D. (2008), Clima României, Ed. Academiei Române, ISBN: 978-973-27-1674-8

14. Sfîcă L. (2007), Nouvelle aproche sur la circulation atmosphérique dans le nord-est de la Roumanie, Actes du XX-eme colloque de l'Association Internationale de Climatologie, Tunis

15. Sfîcă, L., Croitoru A-E., Iordache, I., Ciupertea F-A. (2017), Synoptic conditions generating heat waves and warm spells in Romania, Atmosphere, 8 (3), 50; doi:10.3390/atmos8030050

16. Stăncescu I., Goţi V., Damian D. (1986), Aspecte diferenţiale ale vremii peteritoriul României în perioada de vară determinate de evoluţia dorsalei Anticiclonului Azoric, Culeg. delucr. de Meteorolog., I.M.H., Bucureşti

17. Stoenescu, Șt. M. (1951), Clima Bucegilor, Memorii şi studii, D.G.H., I.M.C., EdituraTehnică, București

18. Stoica C. (1962), Precipitaţii atmosferice în regim antiticlonic, Culeg. delucr. ale I.M. peanul 1960, Bucureşti

19. Tomozeiu, R., Busuioc A., Ștefan, S. (2002), Changes in seasonal mean maximum air temperature in Romania and their connection with large-scale circulation, International Journal of Climatology, 22: 1181-1196 